\title{
Comparison of $7 \alpha$-methyl-19-nortestosterone effectiveness alone or combined with progestins on androgen receptor mediated-transactivation
}

\author{
Rocío García-Becerra, David Ordaz-Rosado, Gabriela Noé ${ }^{1}$, Bertha Chávez, Austin J Cooney ${ }^{2}$ \\ and Fernando Larrea
}

Department of Reproductive Biology, Instituto Nacional de Ciencias Médicas y Nutrición Salvador Zubirán, Vasco de Quiroga No. 15, Mexico City 14000, Mexico, ${ }^{1}$ Instituto Chileno de Medicina Reproductiva, José Victorino Lastarria 29, Santiago, Chile and ${ }^{2}$ Department of Molecular and Cellular Biology, Baylor College of Medicine, One Baylor Plaza, Houston, Texas 77030, USA

Correspondence should be addressed to F Larrea; Email: fernando.larreag@quetzal.innsz.mx

R García-Becerra and D Ordaz-Rosado contributed equally to this work

\begin{abstract}
$7 \alpha$-methyl-19-nortestosterone (MENT) is an androgen with potent gonadotropin inhibitory activity and prostate-sparing effects. These attributes give MENT advantages over testosterone as a male contraceptive, but, as in the case of testosterone, a partial dose-dependent suppression of spermatogenesis has been observed. Combination of testosterone or MENT with synthetic progestins improves the rate of azoospermia; however, it is unknown whether these combinations affect hormone androgenicity or exert synergistic effects via progestational or androgenic interaction. Herein, using transactivation assays, we examined the ability of MENT alone or combined with several 19-nor-derived synthetic progestins to activate androgen receptor (AR)-dependent gene transcription. In addition, the capability of $7 \alpha$-methyl-estradiol ( $7 \alpha-$ methyl- $\left.E_{2}\right)$, an aromatized metabolite of MENT, to transactivate gene transcription via estrogen receptor $\alpha(E R \alpha$; ESR1) or ERß (ESR2) was also investigated. As expected, MENT induced gene transactivation through either the progesterone receptor (PGR) or the AR. MENT was as efficient as progesterone in activating PGR-mediated reporter gene expression, but it was ten times more potent than testosterone and dihydrotestoterone in activating of AR-driven gene expression. The addition of increasing concentrations of other 19-nortestosterone derivatives (norethisterone or levonorgestrel) did not affect, in a significant manner, the ability of MENT to activate AR-dependent reporter gene transcription. The same results were obtained with different cell lines. $7 \alpha$-Methyl- $E_{2}$ resulted in potent estrogen activity via both ER subtypes with efficiency similar to natural $E_{2}$.

These results suggest that the addition of 19-nortestosterone-derived progestins, as a hormonal adjuvant in male fertility strategies for effective spermatogenic suppression, does not display any detrimental effect that would interfere with MENT androgenic transcriptional activity.

Reproduction (2012) $143211-219$
\end{abstract}

\section{Introduction}

Androgen administration to men has two main purposes, as hormonal replacement therapy to support a wide spectrum of physiological needs and as a contraceptive agent for its ability to suppress both gonadotropins and spermatogenesis. Most of the currently available preparations include natural testosterone or its $17 \beta$-hydroxyl ester derivatives, the effects of which on muscle, bone, prostate, sexual behavior and gonadotropin regulation, among others, reflect those of testosterone itself. In general, the biological impact of testosterone is derived from the sum of testosterone actions and its metabolites, mainly $5 \alpha$-dihydrotestosterone (DHT) and estradiol $\left(\mathrm{E}_{2}\right)$.
In contrast to $E_{2}$, whose actions have desirable effects in adult men (Zmuda et al. 1993, Bagatell et al. 1994), DHT has not yet been shown to display any known beneficial effect, but it is considered to be a permissive factor in the progression of benign hyperplasia of the prostate, balding, and acne (Mooradian et al. 1987). An ideal synthetic androgen for men should have the advantages of testosterone in terms of its anabolic effects but with some metabolic restrictions such as not undergoing $5 \alpha$-reduction to DHT, but otherwise aromatization to estrogens. In this regard, it is well known that the addition of a $7 \alpha$-methyl group to 19-nortestosterone increases its androgenic and anabolic actions (Kumar et al. 1999), but prevents 
5a-reduction (Agarwal \& Monder 1988, Kumar et al. 1992). Therefore, the synthetic androgen $7 \alpha$-methyl19-nortestosterone (MENT) seems to be the compound of choice, since it has the beneficial effects of testosterone without the local androgenic side effects of DHT (Sundaram et al. 1994). When administered through implants to healthy men, MENT showed a potent suppressive effect on testicular function and, as in the case of testosterone, its effects on pituitary gonadotropins and sperm counts were dose related (Suvisaari et al. 1997). A number of studies have shown that combination of androgens and androgenic progestins such as levonorgestrel (LNG), etonogestrel (ENG), and norethisterone (NET), which are all 19-nortestosterone derivatives, increases the rate of azoospermia. This combined method allows reduction of the high dose of testosterone needed to suppress gonadotropins and its secondary adverse effects, while maintaining the beneficial peripheral actions of testosterone and, therefore, its potential utility as a male contraceptive (Meriggiola \& Bremner 1997, Anderson \& Baird 2002, Meriggiola et al. 2005, 2006, Meriggiola \& Pelusi 2006, Walton et al. 2007). Although it is well known that some progestins can effectively suppress gonadotropin secretion and have a direct inhibitory effect on Leydig cell steroidogenesis, it remains to be seen whether the hormonal combination has an additive agonist-antagonist androgenic effect. Accordingly, we have studied the functional abilities of MENT alone or in combination with several progestins to transactivate androgen receptor (AR)dependent gene transcription.

\section{Results}

\section{Transactivation of gene transcription via progesterone receptor and $A R$ by MENT and progestins}

Because of known high affinity of MENT for both progesterone receptor (PGR) and AR, we were interested in investigating the effects of MENT on transactivation of transcription via these two receptors. The effects of MENT on receptor-mediated reporter gene transcription were compared with those obtained with progesterone $\left(\mathrm{P}_{4}\right), \mathrm{DHT}$, or testosterone respectively. PGR-mediated activity was studied in the presence of increasing concentrations $\left(1 \times 10^{-12}\right.$ to $\left.10^{-6} \mathrm{M}\right)$ of $\mathrm{P}_{4}$ or MENT as shown in Fig. 1A. In these experiments we also tested, as an additional positive control, another synthetic progestin, nestorone, a highly selective 19-norprogesterone derivative with no androgenic and estrogenic activities (Kumar et al. 2000). As shown, MENT exhibited 2.38 times more transcriptional activity than $\mathrm{P}_{4}$, with effective doses $\left(E D_{50}\right)$ of $7.46 \times 10^{-10}$ and $1.78 \times$ $10^{-9} \mathrm{M}$ for MENT and $\mathrm{P}_{4}$ respectively. As shown in Fig. $1 \mathrm{~A}$, nestorone was shown to be 100 times more potent than $\mathrm{P}_{4}$ with an $\mathrm{ED}_{50}$ of $6.25 \times 10^{-12} \mathrm{M}$. Incubations in the presence of mifepristone (RU486)
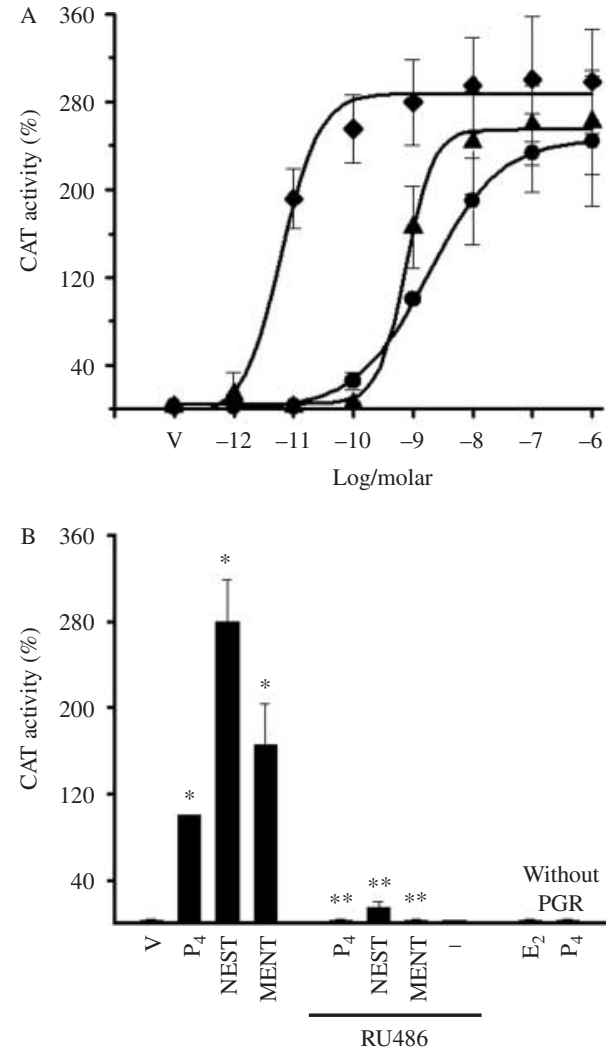

Figure 1 (A) Transcriptional activation via the progesterone receptor (PGR). HeLa cells were transiently transfected using the PRE-Elb-CAT reporter plasmid and the expression vector for PGR. Cells were cultured in the presence of increasing concentrations $\left(10^{-12}\right.$ to $\left.10^{-6} \mathrm{M}\right)$ of $\mathrm{P}_{4}$ (filled circle), MENT (filled triangle), and nestorone (filled diamond). CAT activity was determined in $5 \mu$ g cellular protein. Natural $\mathrm{P}_{4}$ and nestorone were used as natural and synthetic positive controls for the PGR. Each point represents the mean \pm s.D. of three independent experiments and values are expressed as the percentage of the CAT activity induced by $10^{-9} \mathrm{M} \mathrm{P}_{4}(100 \%)$. (B) Effects of mifepristone (RU486), a PGR antagonist on PGR-driven reporter gene transcription. Transfected HeLa cells were incubated in the presence of $1 \times 10^{-9} \mathrm{M}$ of $\mathrm{P}_{4}$, nestorone, and MENT with or without RU486. No reporter gene transcription was observed in control incubations in the presence of $E_{2}$ or in the presence of $\mathrm{P}_{4}$ in non-PGR transfected cells. ${ }^{*} P<0.005$ vs vehicle $(\mathrm{V}) ;{ }^{* *} P<0.005$ vs control incubations without RU486. The value obtained with $\mathrm{P}_{4}$ at the dose of $1 \times 10^{-9} \mathrm{M}$ was taken as $100 \%$ transcriptional activity. MENT, $7 \alpha$-methyl-19-nortestosterone.

resulted in the inhibition of MENT and nestorone effects upon PGR-driven transcriptional activation (Fig. 1B). No effects, different from control vehicle, were observed with mifepristone alone or with $\mathrm{DHT}$, including with $\mathrm{P}_{4}$ on cells not transfected with PGR.

A similar experiment but using cells transfected with the AR is shown in Fig. 2A. The androgenic activity of MENT was compared with those of DHT and testosterone. All three androgens significantly increased the reporter activity in a dose-dependent manner. In this assay, MENT was about 100 times more potent than testosterone as shown by the calculated $\mathrm{ED}_{50}$ values 

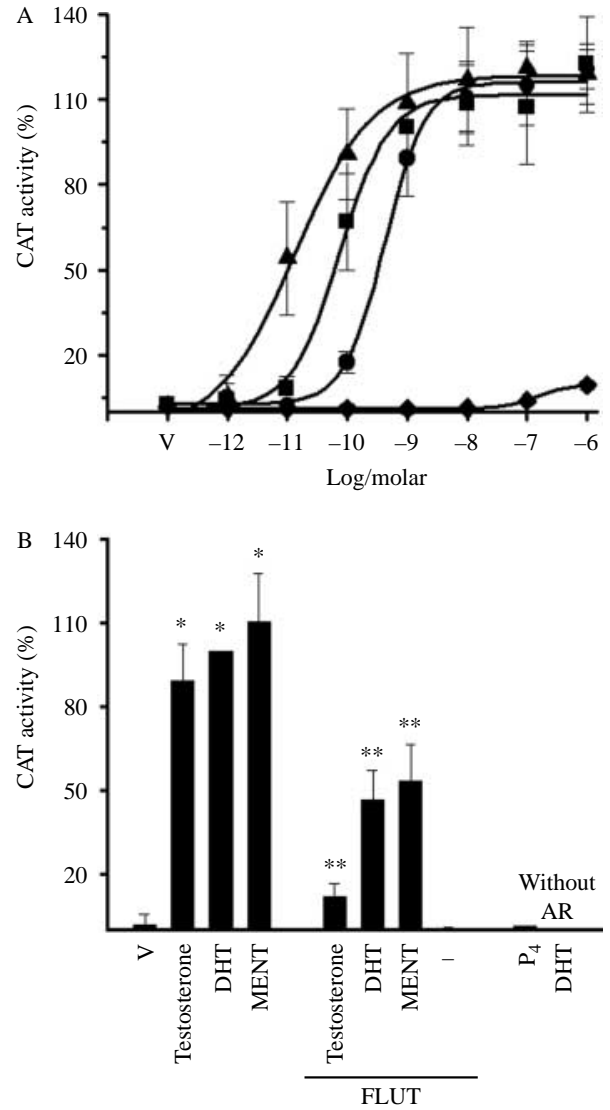

Figure 2 (A) Transcriptional activation via the androgen receptor (AR). HeLa cells were transiently transfected using the PRE-Elb-CAT reporter plasmid and the expression vector for AR. Cells were cultured in the presence of increasing concentrations of testosterone (filled circle), DHT (filled square), MENT (filled triangle) and nestorone (filled diamond). Natural testosterone and DHT were used as natural positive controls for the AR. Each point represents the mean \pm the S.D. of three independent experiments and values are expressed as the percentage of CAT activity induced by $1 \times 10^{-9} \mathrm{M} \mathrm{DHT}(100 \%)$. Nestorone, which does not bind to the AR, was used as a negative control. (B) Effects of flutamide (FLUT), an AR antagonist, on AR-driven reporter gene transcription. Transfected HeLa cells were incubated in the presence of $1 \times 10^{-9} \mathrm{M}$ of testosterone, DHT, and MENT, with or without FLUT. ${ }^{*} P<0.005$ vs vehicle $(\mathrm{V})$; ${ }^{* *} P<0.005$ vs control incubations without FLUT. The value obtained with DHT at the dose of $1 \times 10^{-9} \mathrm{M}$ was taken as $100 \%$ activity. DHT, $5 \alpha$-dihydrotestosterone; MENT, $7 \alpha$-methyl-19-nortestosterone; CAT, chloramphenicol acetyltransferase.

(MENT, $3.42 \times 10^{-12} \mathrm{M}$; DHT, $7.0 \times 10^{-11} \mathrm{M}$; and testosterone, $\left.4.15 \times 10^{-10} \mathrm{M}\right)$. All transcriptional responses were significantly inhibited by the addition of flutamide (Fig. 2B). No effects, different from control vehicle, were observed with flutamide alone or $\mathrm{P}_{4}$ or with DHT on cells not transfected with AR.

As shown in Fig. 3, both NET and LNG induced reporter gene transcription through the AR and PGR. Through both receptors, LNG induced significantly higher transcriptional responses than NET and they were significantly inhibited in the presence of flutamide or RU486 respectively.

\section{Effects of addition of progestins on MENT-induced transcriptional activation}

The potency of MENT on AR-driven reporter gene transcription was investigated in the presence of increasing concentrations of selected progestins. The potency of MENT was expressed as the ratio of androgen to $\mathrm{P}_{4}$-driven transcriptional activation ( $\mathrm{ED}_{50}$ indexes) as a measure of androgenicity vs progestogenicity (selectivity index). The results were compared with the selectivity index of MENT obtained in the absence or presence of progestins. Figure 4 shows the induction of AR-mediated reporter transcription by increasing concentrations of MENT $\left(1 \times 10^{-11}\right.$ to $\left.1 \times 10^{-8} \mathrm{M}\right)$ in the presence or absence of NET and LNG at a concentration equal to their $\mathrm{ED}_{50}$ to activate androgen-driven reporter expression $\left(2.07 \times 10^{-9}\right.$ and $1.05 \times 10^{-10} \mathrm{M}$ for NET and LNG respectively). The activity of DHT at the concentration of $1 \times 10^{-9} \mathrm{M}$ was taken as $100 \%$ response. The addition of NET and LNG did not modify the ability of MENT to activate androgen-driven reporter gene transcription $\left(\mathrm{ED}_{50}=6.04 \times 10^{-12}\right.$ and $2.23 \times$ $10^{-12} \mathrm{M}$ for NET and LNG respectively). Incubations of MENT $\left(1 \times 10^{-11}\right.$ to $\left.1 \times 10^{-8} \mathrm{M}\right)$ in the presence of increasing concentrations of NET or LNG $\left(1 \times 10^{-10}\right.$ to $1 \times 10^{-8} \mathrm{M}$ ) did not result in a significant change in the MENT selectivity index compared with that obtained in the absence of progestins (Table 1). Incubations in the presence of increasing concentrations of nestorone, a synthetic progestin, which does not bind with the AR and used as a negative control, did not affect MENT-induced reporter transcriptional activity. Similar results on the effects of addition of progestins on MENT induced AR-mediated transactivation in HeLa cells were also observed in an AR transfected PC3 prostate cell line (data not shown) and in HEK-293 and T47D AR-positive cells (Fig. 5A and B respectively).

\section{Transactivation of estrogen receptors by the aromatized MENT metabolite $7 \alpha$-methyl- $E_{2}$}

In vitro, MENT undergoes aromatization to the active estrogen $7 \alpha$-methyl- $E_{2}$ (LaMorte et al. 1994); it was therefore thought important in this study to investigate

Table 1 Transcriptional effective stimulatory dose $\left(\mathrm{ED}_{50}\right)$ and the androgen-to-progestin (AR/PGR $\left.{ }^{a}\right)$ indexes of $7 \alpha$-methyl-19-nortestosterone (MENT) alone or combined with 19-nor-derived progestins.

\begin{tabular}{|c|c|c|}
\hline Ligand $(M)$ & $\begin{array}{l}\text { MENT-ED }_{50} \\
\text { AR (M) }\end{array}$ & $\begin{array}{c}\text { MENT-ED } \\
\text { AR/PG-index } \\
\text { ARG }\end{array}$ \\
\hline MENT & $3.42 \times 10^{-12}$ & $5.13 \times 10^{-3}$ \\
\hline MENT + NET -10 & $2.59 \times 10^{-12}$ & $3.47 \times 10^{-3}$ \\
\hline MENT+ NET $^{-9}$ & $3.52 \times 10^{-12}$ & $4.72 \times 10^{-3}$ \\
\hline MENT + NET ${ }^{-8}$ & $4.02 \times 10^{-12}$ & $5.39 \times 10^{-3}$ \\
\hline MENT + LNG $^{-10}$ & $2.77 \times 10^{-12}$ & $3.71 \times 10^{-3}$ \\
\hline MENT + LNG ${ }^{-9}$ & $1.74 \times 10^{-12}$ & $2.33 \times 10^{-3}$ \\
\hline $\mathrm{MENT}+\mathrm{LNG}^{-8}$ & $1.63 \times 10^{-12}$ & $2.18 \times 10^{-3}$ \\
\hline
\end{tabular}

${ }^{\mathrm{a} M E N T-P G R ~} \mathrm{ED}_{50}=7.46 \times 10^{-10} \mathrm{M}$. 


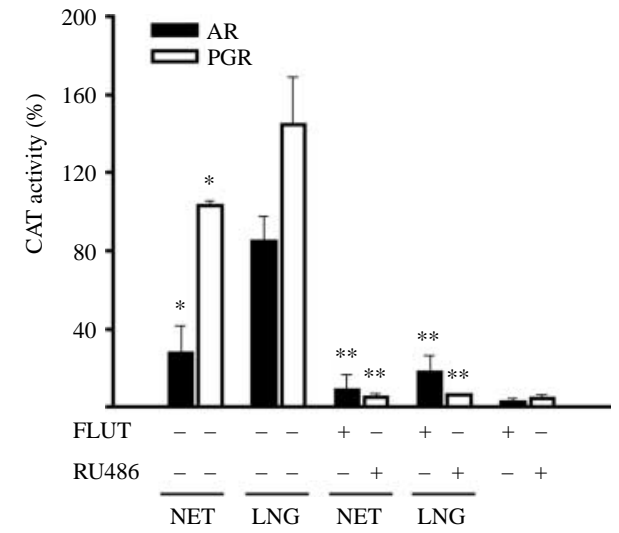

Figure 3 Transcriptional activation via the androgen receptor (AR) and progesterone receptor (PGR) by NET and LNG in HeLa cells respectively. Incubations were done in the presence of $1 \times 10^{-9} \mathrm{M}$ of agonist with or without $1 \times 10^{-7}$ and $1 \times 10^{-4} \mathrm{M}$ of RU486 and FLUT respectively. ${ }^{*} P<0.05$ vs $\mathrm{LNG}$; ${ }^{* *} P<0.05$ vs incubations in the absence of antagonists. The value obtained with $\mathrm{DHT}$ and $\mathrm{P}_{4}$ at the dose of $1 \times 10^{-9} \mathrm{M}$ was taken as $100 \%$ transcriptional activity. No effects upon transcription were observed with antagonists only. NET, norethisterone; LNG, levonorgestrel; FLUT, flutamide;

DHT, $5 \alpha$-dihydrotestosterone.

the ability of this estrogen to activate transcription via both estrogen receptor (ER) subtypes. Figs 6 and 7 show the estrogen agonist activity of both $E_{2}$ and $7 \alpha$-methyl- $E_{2}$ in terms of transactivation via the ESR1 or ESR2 respectively. As can be seen, the aromatized metabolite of MENT activated reporter gene transcription through both receptors with similar $\mathrm{ED}_{50}$ values $\left(8.04 \times 10^{-12}\right.$ and $1.27 \times 10^{-10} \mathrm{M}$ for the ESR1 and ESR2 respectively), to those observed with $E_{2}\left(7.69 \times 10^{-12}\right.$ and $1.84 \times$ $10^{-10} \mathrm{M}$ for the ESR1 and ESR2 respectively). Incubations in the presence of $\mathrm{ICl}$, an ER antagonist, resulted in a significant inhibition of $7 \alpha$-methyl- $E_{2}$ effects upon transcription via the ESR1 (Fig. 6B) and ESR2 (Fig. 7B). No effects, different from the control vehicle, were obtained with $\mathrm{ICl}$ alone, nestorone or with $\mathrm{E}_{2}$ on cells not transfected with ER subtypes.

\section{Discussion}

Addition of a $7 \alpha$-methyl group to 19 -nortestosterone significantly enhances its androgenic potency and ability to bind to the AR; however, this $7 \alpha$-methyl-substituted steroid is not reduced by prostatic $5 \alpha$-reductase (Liao et al. 1973). Indeed, in contrast to testosterone, MENT is less potent on male accessory sex glands compared with its ability to suppress gonadotropins; MENT otherwise can be aromatized to $7 \alpha$-methyl- $E_{2}$ (LaMorte et al. 1994). These observations indicate that MENT, as a component for androgen replacement therapy or male contraceptive, has health-promoting effects, particularly by avoiding hyperstimulative effects on the prostate, including prostatespecific antigen (Kumar et al. 1992, Morali et al. 1993, Cummings et al. 1998, Anderson et al. 2003, von
Eckardstein et al. 2003, Walton et al. 2007), and those derived from MENT aromatization (LaMorte et al. 1994, Anderson et al. 1999).

Suppression of gonadotropin secretion with exogenously administered testosterone and therefore testicular activity is important for hormone-based male contraception approach. In this regard, MENT when administered to healthy men leads to gonadotropin suppression and inhibition of spermatogenesis making it potentially useful as a male contraceptive (von Eckardstein et al. 2003). In the case of testosterone, combination with gonadotropin-inhibiting agents such as progestins results in a more effective formulation for spermatogenic suppression than testosterone alone (Bebb et al. 1996). Recently, Walton et al. (2007) showed that combination of MENT with a progestin resulted in rapid inhibition of spermatogenesis similar to the combined testosterone formulation and pointed out the importance of the
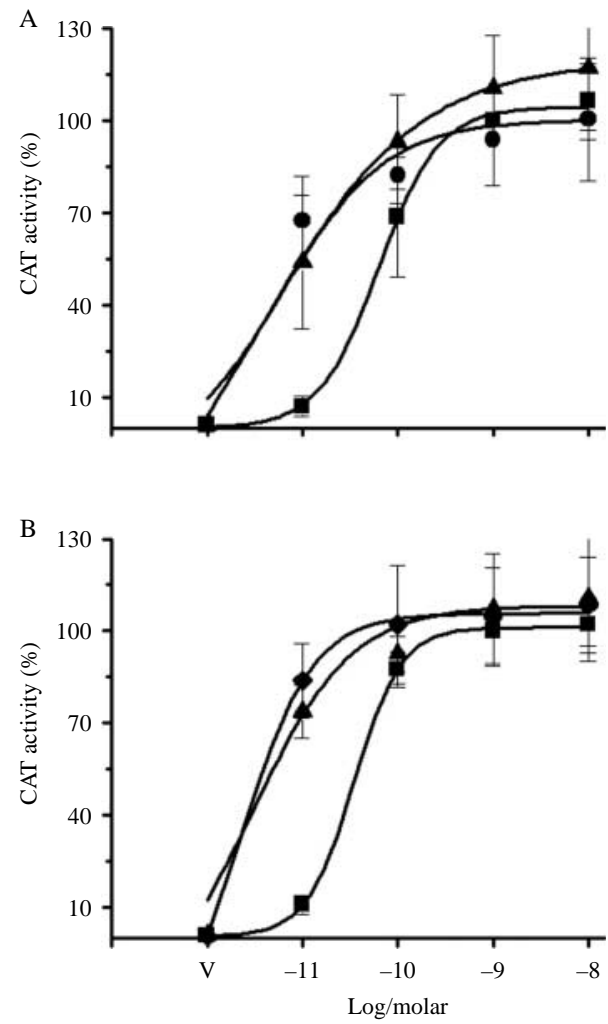

Figure 4 Dose-response curves for MENT (filled triangle), DHT (filled square), and MENT plus NET (filled circle) or LNG (filled diamond) on AR-dependent gene reporter activation. HeLa cells cotransfected with PRE-Elb-CAT reporter plasmid and the expression vector for AR were incubated in the presence of increasing concentrations of MENT alone or in combination with a single dose of $2.07 \times 10^{-9} \mathrm{M} \mathrm{NET}(\mathrm{A})$ or $1.05 \times 10^{-10} \mathrm{M}$ LNG (B). These doses corresponded to their respective $\mathrm{ED}_{50}$ value of NET and LNG to activate AR-dependent gene transcription respectively. Each point represents the mean \pm s.D. of three independent experiments and values are expressed as the percentage of the CAT activity induced by $1 \times 10^{-9} \mathrm{M} \mathrm{DHT}(100 \%)$.

DHT, $5 \alpha$-dihydrotestosterone; MENT, $7 \alpha$-methyl-19-nortestosterone; CAT, chloramphenicol acetyltransferase. 
synthetic progestin dose over the androgen dose in improving spermatogenesis suppression. However, subjects treated with four MENT implants exhibited higher and longer spermatogenesis suppression (von Eckardstein et al. 2003) than subjects treated with two MENT implants plus two ENG implants (Walton et al. 2007). Four MENT implants induced azoospermia or severe oligozoospermia (sperm count $<1 \times 10^{6} / \mathrm{ml}$ ) in $82 \%$ and $100 \%$ of subjects during the first and second 6 -month periods of treatment respectively. Thus, during the last 6 months of treatment, MENT alone was as effective as testosterone undecanoate plus NET enanthate administered at 8-week intervals (Meriggiola et al. 2005).

Several synthetic progestins behave as weak androgens, particularly medroxyprogesterone acetate, LNG, and NET (Perez-Palacios et al. 1981, Bergink et al. 1983, Kloosterboer et al. 1988, Garcia-Becerra et al. 2004). Indeed, in a previous publication from this laboratory these compounds were able to activate AR-dependent reporter gene expression, with LNG acting as the strongest activator (Garcia-Becerra et al. 2004). In males, administration of $\mathrm{P}_{4}$ or synthetic progestins, in addition to their inhibitory effects on Leydig cell steroidogenesis (El-Hefnawy \& Huhtaniemi 1998) and $5 \alpha$-reductase activity (Mauvais-Jarvis et al. 1974), inhibit gonadotropin secretion and suppresses spermatogenesis (Anderson \& Baird 2002). Although the addition of some other antigonadotropic compound ensures effective suppression of gonadotropin secretion, it is still unknown whether the hormonal combination may or may not affect, in an agonist-antagonist fashion, the androgenic activity of MENT at the level of AR. This observation is of particular importance since androgens are required to maintain a number of physiological parameters in men, including, among others, muscle metabolism, erythropoiesis, sexual activity, and function of accessory sex organs. Therefore, we thought it was of interest to evaluate the ability of MENT alone or combined with other synthetic progestins to activate gene transcription via the AR.

In this study, we confirmed the androgenic and progestational activities of MENT. Both MENT and synthetic progestins activated AR- and PGR-dependent reporter gene transcription, with MENT being the strongest AR activator. We used the ratio of androgen to $\mathrm{P}_{4}$ transcriptional activation potencies ( $E D_{50}$ indexes) of MENT, alone or in the presence of various progestins (selectivity index), as a measure of androgen vs progestogenic activity. Results were normalized against MENT's $\mathrm{ED}_{50}$ for PGR in the absence of progestins. The smaller the ratio, the greater the difference between the androgen-to- $\mathrm{P}_{4}$ transcriptional responses. Changes in MENT selectivity index values were taken as indicating a decrease or increase in androgenic transcriptional activity. It was interesting to see that neither $\mathrm{P}_{4}$ nor DHT activated transcription through the AR and PGR respectively.
In this study, none of the progestins with (LNG and NET) or without (nestorone) affinity for the AR was able to significantly modify the MENT selectivity index. These results indicated that synthetic progestins, at the doses tested, did not act as agonists or antagonists of MENT upon the AR-dependent transcriptional assay, suggesting that addition of progestins to actual or future MENT formulations will not interfere with their expected androgenic biological responses. It is also important to mention that although MENT does not undergo further metabolism to $5 \alpha$-reduced metabolites, reduction of the 4-ene-double bond of LNG and NET does not change
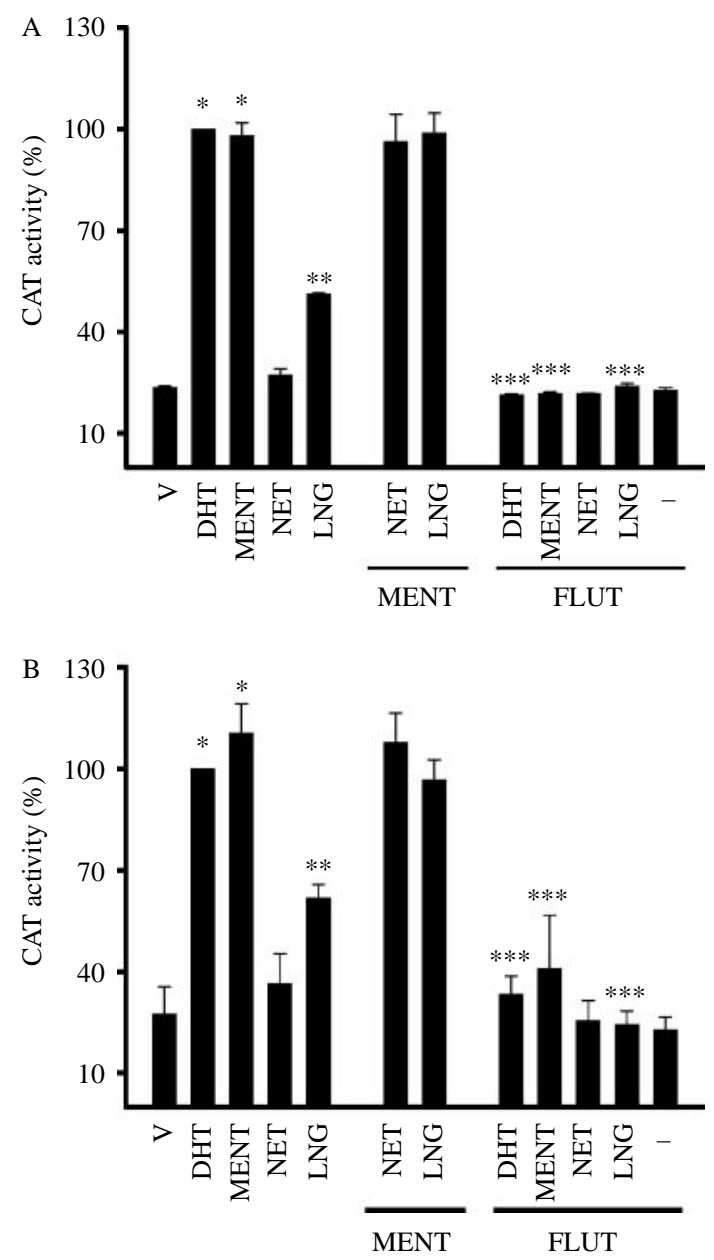

Figure 5 Transcriptional activation via the androgen receptor (AR) by MENT in the presence or absence of NET and LNG in HEK-293 (A) and T47D cells (B). Incubations were done in the presence of $1 \times 10^{-9} \mathrm{M}$ of MENT in the absence or presence of NET $\left(2.07 \times 10^{-9} \mathrm{M}\right)$ or LNG $\left(1.05 \times 10^{-10} \mathrm{M}\right)$. Control incubations were carried out in the presence of $1 \times 10^{-4} \mathrm{M}$ flutamide (FLUT). ${ }^{*} P<0.001$ vs vehicle $(\mathrm{V}) ;{ }^{* *} P<0.05$ vs $\mathrm{NET} ;{ }^{* * *} P<0.001$ vs incubations in the absence of antagonists.

The value obtained with DHT at the dose of $1 \times 10^{-9} \mathrm{M}$ was taken as $100 \%$ transcriptional activity. No effects upon transcription were observed with the antagonist only. Each bar represents the mean \pm s.D. of three independent experiments. DHT, $5 \alpha$-dihydrotestosterone; MENT, $7 \alpha$-methyl-19-nortestosterone; CAT, chloramphenicol acetyltransferase. NET, norethisterone; LNG, levonorgestrel; FLUT, flutamide. 

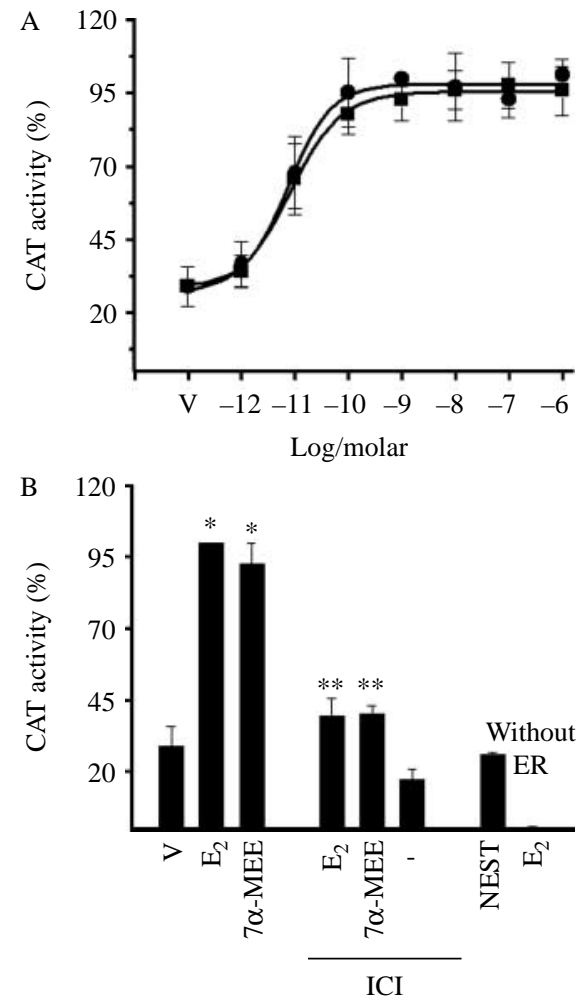

Figure 6 (A) ESR1-mediated gene reporter activation by $7 \alpha$-methyl- $E_{2}$. HeLa cells cotransfected with the estrogen-responsive reporter plasmid (ERE-E1b-CAT) and the expression vector for ESR1 were incubated in the presence of increasing concentrations of $7 \alpha$-methyl- $E_{2}$ (filled square) or $\mathrm{E}_{2}$ (filled circle). (B) Additional control incubations were done in the presence of $7 \alpha$-methyl- $E_{2}$ or $E_{2}$ at the dose of $1 \times 10^{-9} \mathrm{M}$ with or without $\mathrm{ICl}$, an ER antagonist. No reporter gene transcription was observed in incubations in the presence of nestorone or $E_{2}$ in nonESR1 transfected cells. Each point represents the mean \pm s.D. of three independent experiments and values are expressed as the percentage of the CAT activity induced by $1 \times 10^{-9} \mathrm{M} \mathrm{E}_{2}(100 \%)$. ${ }^{*} P<0.005$ vs vehicle $(\mathrm{V}) ;{ }^{* *} P<0.005$ vs incubations in the absence of $\mathrm{ICI}$.

ESR1, estrogen receptor 1; CAT, chloramphenicol acetyltransferase.

significantly their androgenic transcriptional activities (Sundaram et al. 1995, Garcia-Becerra et al. 2004) so as to have unwanted effects upon the prostate. Our results may also support promising approaches for male fertility regulation in terms of raising the dose of progestins to improve sperm suppression and minimize MENT nonreproductive androgenic effects (Anderson \& Baird 2002, von Eckardstein et al. 2003, Walton et al. 2007).

Although the affinity of MENT and progestins for the AR was not estimated, particularly due to the lack of radiolabeled ligands, special attention should be paid to recent observations of Simons (2008) showing that changes in receptor sequence may alter transcriptional activities without affecting receptor binding affinities. This observation, suggesting that a single ligand concentration can differentially affect gene transactivation, should be taken into consideration when data obtained in vitro, as in this study, are thought to be applied to in vivo conditions. In addition, receptor mutations may also increase affinity for coactivators or corepressors, as well as show differential activity depending on the use of promoters. In this study, instead of using different reporter gene constructs, we used different cell lines with or without endogenous AR expression. In these experiments similar if not identical results were obtained among all cell lines studied. However, additional experiments should be performed to investigate receptor structural conformations and the binding of selective co-regulatory proteins in the presence of different ligands, which will importantly contribute to a better understanding of MENT selective actions on the AR.

In this study, we also tested the ability of $7 \alpha$-methyl- $E_{2}$, the aromatized metabolite of MENT, to transactivate reporter gene expression via both ESR1 and ESR2. Our results confirmed and established the fully estrogenic activity of $7 \alpha$-methyl- $E_{2}$ throughout both ER subtypes. Although at present it is not known to what extent MENT is metabolized to an estrogenic compound in vivo, it is well known that metabolism of testosterone, particularly
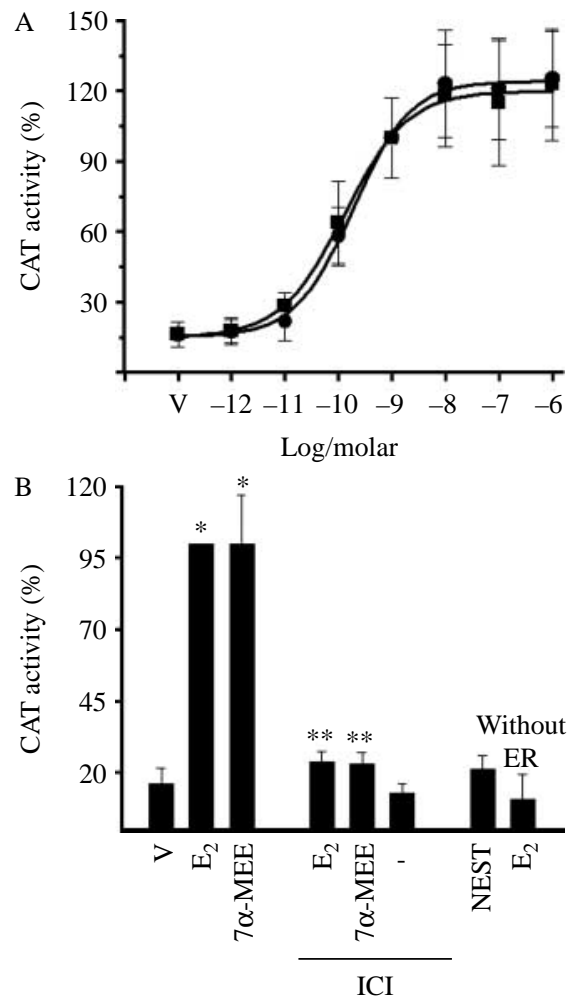

Figure 7 (A) ESR2-mediated gene reporter activation by $7 \alpha$-methyl- $E_{2}$. HeLa cells were cotransfected and incubated in the presence of increasing concentrations of $7 \alpha$-methyl- $E_{2}$ (filled square) or $E_{2}$ (filled circle) as indicated in Fig. 6. (B) Control incubations were performed as indicated in Fig. 6. Each point represents the mean \pm s.D. of three independent experiments and values are expressed as the percentage of the CAT activity induced by $1 \times 10^{-9} \mathrm{M} \mathrm{E}_{2}(100 \%)$. ${ }^{*} P<0.005$ vs vehicle $(\mathrm{V}) ;{ }^{* *} P<0.005$ vs incubations in the absence of ICI. ESR1, estrogen receptor 1 ; CAT, chloramphenicol acetyltransferase. 
to aromatized derivatives, is important in mediating its effects on several physiological processes, including control of gonadotropin secretion, maintenance of bone mass, and sexual behavior (Morali et al. 1977, Finkelstein et al. 1991, Vanderschueren et al. 2004). The fact that $7 \alpha$-methyl- $E_{2}$ resulted in a potent estrogenic activity via both ER subtypes suggests that some anabolic actions of MENT may be mediated by this metabolite. However, whether MENT biotransformation to an active estrogen is responsible for some androgen-dependent outcomes observed in animal and human studies is still uncertain.

In conclusion, this study demonstrated that combination of MENT and synthetic progestins with affinity for $A R$ results in activation of gene transcription in a similar manner to that obtained with MENT alone. These results indicated that addition of progestins to MENT formulations for effective spermatogenic suppression, as a promising approach for male fertility regulation, may not interfere with the beneficial androgenic effects of MENT. Furthermore, the fact that MENT does not undergo $5 \alpha$-reduction, in addition to its ability to be aromatized to an estrogen metabolite with activity via both ER subtypes, makes MENT an ideal synthetic androgen for men.

\section{Materials and Methods}

\section{Reagents}

Non-radioactive $\mathrm{P}_{4}, \mathrm{DHT}, \mathrm{E}_{2}$, testosterone, and trypsin (type III) were purchased from Sigma-Aldrich. $\left[{ }^{3} \mathrm{H}\right]$ Chloramphenicol (specific activity, $38.9 \mathrm{Ci} / \mathrm{mmol}$ ) was purchased from DuPont NEN Research Products (Boston, MA, USA). Unlabeled RU-486 (RU 38486, mifepristone) was a gift from Roussell Uclaf (Romainville, France) and the antiestrogen ICI 182780 was purchased from AstraZeneca. Radioactivity was measured in a Beckman LS 6500 scintillation system (Beckman Coulter, Brea, CA, USA) using Biodegradable Counting Scintillant (Amersham) as the counting solution. Cell culture medium was purchased from Life Technologies Corporation. Fetal bovine serum (FBS) was obtained from HyClone Laboratories, Inc. (Logan, UT, USA). MENT was kindly donated by the Population Council's Center for Biomedical Research (New York, NY, USA) and $7 \alpha$-methyl- $E_{2}$ and nestorone from Instituto Chinelo de Medicina Reproductiva, Santiago, Chile. Authentic NET (17 $\alpha$-ethynyl-17 $\beta$-hydroxy-4-gonen-3-one) and LNG (13 $\beta$-ethyl-17 $\alpha$-ethynyl-17 $\beta$-hydroxy-4-gonen-3-one) were kindly provided by Schering Mexicana S.A. (Mexico City, Mexico).

\section{Plasmids}

The expression vectors for $h_{P G R_{B}}\left(p C R 3.1-h P G R_{B}\right), E S R 1$ (pCR3.1-hESR1), ESR2 (pCR3.1-hESR2), and AR (pcDNAHiSARmcs) for in vitro transcription and translation have been described previously (Allan et al. 1992, Kraichely et al. 2000). In the case of transactivation assays, the expression vectors for human ESR1 and ESR2 ( $\mathrm{pCMV}_{5}$-hESR1 and $\mathrm{pCMV} \mathrm{F}^{-\mathrm{hESR} 2)}$ containing the coding sequence of the ESR1 and ESR2 were kindly provided by Drs B S Katzenellenbogen, University of Illinois (Urbana, IL, USA) and J- $\AA$ Gustafsson, Karolinska Institute (Huddinge, Sweden) respectively. The pLEN-hPGR was generated by inserting the full-length human $P_{B} R_{B} C D N A$ into the BamHI site of the pLEN vector. The pSVhAR.BHEXE vector was kindly provided by $\operatorname{Dr} \mathrm{E}$ L Young (National University of Singapore). The estrogen-responsive reporter plasmid (ERE-E1b-CAT) contains a fragment of the vitellogenin A2 gene promoter (positions -331 to -87 ) upstream of the adenovirus E1b TATA box fused to the chloramphenicol acetyltransferase (CAT) gene (Allgood et al. 1993, Larrea et al. 2001). The androgen and $P_{4}$ responsive reporter plasmid (PRE-E1b-CAT) contains an oligonucleotide containing a $\mathrm{P}_{4} /$ androgen response element upstream of the adenovirus $\mathrm{E} 1 \mathrm{~b}$ TATA box fused to the CAT gene as described previously.

\section{Transient transfections}

HeLa, PC-3, HEK-293, and T47D human cell lines were obtained from the American Type Culture Collection (Rockville, MD, USA). The cells were plated the day before transfections, at a density of $3.0 \times 10^{5}$ cells/well per 6 -well plate, in DMEM without phenol red (DMEM-HG), which was supplemented with $5 \%$ stripped FBS and $100 \mathrm{U} / \mathrm{ml}$ of penicillin and $100 \mu \mathrm{g} / \mathrm{ml}$ streptomycin and incubated in $5 \% \mathrm{CO}_{2}$ at $37^{\circ} \mathrm{C}$. Transfections were performed as described previously (Larrea et al. 2001). Briefly, the medium containing the transfection complexes was added to the cell monolayer and after incubation at $37^{\circ} \mathrm{C}$ for $3 \mathrm{~h}$, the plates containing the transfection complexes were rinsed with PBS and $3 \mathrm{ml}$ of supplemented DMEM-HG was added to each well. Twentyfour hours later, the medium was replaced with the same medium containing the compounds of interest at various concentrations $\left(10^{-12}\right.$ to $\left.10^{-6} \mathrm{M}\right)$. DMSO or ethanol was used as vehicle. CAT activity using $5 \mu \mathrm{g}$ protein, $25 \mu \mathrm{g}$ butyryl coenzyme-A (Sigma-Aldrich), $2 \times 10^{5}$ c.p.m. of xyleneextracted $\left[{ }^{3} \mathrm{H}\right]$ chloramphenicol in $0.25 \mathrm{M}$ Tris- $\mathrm{HCl}, \mathrm{pH} 8.0$, was assayed as described previously (Larrea et al. 2001). Statistical significance was established by two-tailed $t$-test. Receptor binding assays on HeLa cells transfected with the PGR or AR demonstrated affinity constants $\left(K_{d}=1.8 \times 10^{-9}\right.$ and $0.32 \times 10^{-9} \mathrm{M}$ respectively), within values previously reported for these receptors under native conditions.

\section{Declaration of interest}

The authors declare that there is no conflict of interest that could be perceived as prejudicing the impartiality of the research reported.

\section{Funding}

This study was supported in part by grants from the Contraceptive Research and Development Program (CONRAD), Arlington, VA (to A J Cooney and F Larrea) and the Consejo Nacional de Ciencia y Tecnología (CONACyT), Mexico City, Mexico (to F Larrea). 


\section{Acknowledgements}

We acknowledge, with thanks, the Population Council, Center for Biomedical Research, New York, NY, for donation of MENT.

\section{References}

Agarwal AK \& Monder C 1988 In vitro metabolism of 7 alpha-methyl19 -nortestosterone by rat liver, prostate, and epididymis. Endocrinology 123 2187-2193. (doi:10.1210/endo-123-5-2187)

Allan GF, Leng X, Tsai SY, Weigel NL, Edwards DP, Tsai MJ \& O'Malley BW 1992 Hormone and antihormone induce distinct conformational changes which are central to steroid receptor activation. Journal of Biological Chemistry 267 19513-19520.

Allgood VE, Oakley RH \& Cidlowski JA 1993 Modulation by vitamin B6 of glucocorticoid receptor-mediated gene expression requires transcription factors in addition to the glucocorticoid receptor. Journal of Biological Chemistry 268 20870-20876.

Anderson RA \& Baird DT 2002 Male contraception. Endocrine Reviews 23 735-762. (doi:10.1210/er.2002-0002)

Anderson RA, Martin CW, Kung AW, Everington D, Pun TC, Tan KC, Bancroft J, Sundaram K, Moo-Young AJ \& Baird DT 1999 7Alphamethyl-19-nortestosterone maintains sexual behavior and mood in hypogonadal men. Journal of Clinical Endocrinology and Metabolism 84 3556-3562. (doi:10.1210/jc.84.10.3556)

Anderson RA, Wallace AM, Sattar N, Kumar N \& Sundaram K 2003 Evidence for tissue selectivity of the synthetic androgen 7 alpha-methyl-19-nortestosterone in hypogonadal men. Journal of Clinical Endocrinology and Metabolism 88 2784-2793. (doi:10.1210/jc.2002-021960)

Bagatell CJ, Knopp RH, Rivier JE \& Bremner WJ 1994 Physiological levels of estradiol stimulate plasma high density lipoprotein2 cholesterol levels in normal men. Journal of Clinical Endocrinology and Metabolism 78 855-861. (doi:10.1210/jc.78.4.855)

Bebb RA, Anawalt BD, Christensen RB, Paulsen CA, Bremner WJ \& Matsumoto AM 1996 Combined administration of levonorgestrel and testosterone induces more rapid and effective suppression of spermatogenesis than testosterone alone: a promising male contraceptive approach. Journal of Clinical Endocrinology and Metabolism 81 757-762. (doi:10.1210/jc.81.2.757)

Bergink EW, van Meel F, Turpijn EW \& van der Vies J 1983 Binding of progestagens to receptor proteins in MCF-7 cells. Journal of Steroid Biochemistry 19 1563-1570. (doi:10.1016/0022-4731(83)90371-0)

Cummings DE, Kumar N, Bardin CW, Sundaram K \& Bremner WJ 1998 Prostate-sparing effects in primates of the potent androgen 7alphamethyl-19-nortestosterone: a potential alternative to testosterone for androgen replacement and male contraception. Journal of Clinical Endocrinology and Metabolism 83 4212-4219. (doi:10.1210/jc.83. 12.4212)

von Eckardstein S, Noe G, Brache V, Nieschlag E, Croxatto H, Alvarez F, Moo-Young A, Sivin I, Kumar N, Small M et al. 2003 A clinical trial of 7 alpha-methyl-19-nortestosterone implants for possible use as a longacting contraceptive for men. Journal of Clinical Endocrinology and Metabolism 88 5232-5239. (doi:10.1210/jc.2002-022043)

El-Hefnawy T \& Huhtaniemi I 1998 Progesterone can participate in downregulation of the luteinizing hormone receptor gene expression and function in cultured murine Leydig cells. Molecular and Cellular Endocrinology 137 127-138. (doi:10.1016/S0303-7207(98)00002-1)

Finkelstein JS, O'Dea LS, Whitcomb RW \& Crowley WF Jr 1991 Sex steroid control of gonadotropin secretion in the human male. II. Effects of estradiol administration in normal and gonadotropin-releasing hormonedeficient men. Journal of Clinical Endocrinology and Metabolism 73 621-628. (doi:10.1210/jcem-73-3-621)

Garcia-Becerra R, Cooney AJ, Borja-Cacho E, Lemus AE, Perez-Palacios G \& Larrea F 2004 Comparative evaluation of androgen and progesterone receptor transcription selectivity indices of 19-nortestosterone-derived progestins. Journal of Steroid Biochemistry and Molecular Biology 91 21-27. (doi:10.1016/j.jsbmb.2004.02.003)
Kloosterboer HJ, Vonk-Noordegraaf CA \& Turpijn EW 1988 Selectivity in progesterone and androgen receptor binding of progestagens used in oral contraceptives. Contraception 38 325-332. (doi:10.1016/0010-7824 (88)90104-7)

Kraichely DM, Sun J, Katzenellenbogen JA \& Katzenellenbogen BS 2000 Conformational changes and coactivator recruitment by novel ligands for estrogen receptor-alpha and estrogen receptor-beta: correlations with biological character and distinct differences among SRC coactivator family members. Endocrinology 141 3534-3545. (doi:10.1210/en.141. 10.3534)

Kumar N, Didolkar AK, Monder C, Bardin CW \& Sundaram K 1992 The biological activity of 7 alpha-methyl-19-nortestosterone is not amplified in male reproductive tract as is that of testosterone. Endocrinology $\mathbf{1 3 0}$ 3677-3683. (doi:10.1210/en.130.6.3677)

Kumar N, Crozat A, Li F, Catterall JF, Bardin CW \& Sundaram K 1999 7Alpha-methyl-19-nortestosterone, a synthetic androgen with high potency: structure-activity comparisons with other androgens. Journal of Steroid Biochemistry and Molecular Biology 71 213-222. (doi:10.1016/S0960-0760(99)00143-0)

Kumar N, Koide SS, Tsong Y \& Sundaram K 2000 Nestorone: a progestin with a unique pharmacological profile. Steroids 65 629-636. (doi:10. 1016/S0039-128X(00)00119-7)

LaMorte A, Kumar N, Bardin CW \& Sundaram K 1994 Aromatization of 7 alpha-methyl-19-nortestosterone by human placental microsomes in vitro. Journal of Steroid Biochemistry and Molecular Biology $\mathbf{4 8}$ 297-304. (doi:10.1016/0960-0760(94)90160-0)

Larrea F, Garcia-Becerra R, Lemus AE, Garcia GA, Perez-Palacios G, Jackson KJ, Coleman KM, Dace R, Smith CL \& Cooney AJ 2001 A-ring reduced metabolites of 19-nor synthetic progestins as subtype selective agonists for ER alpha. Endocrinology 142 3791-3799. (doi:10.1210/en. 142.9.3791)

Liao S, Liang T, Fang S, Castaneda E \& Shao TC 1973 Steroid structure and androgenic activity. Specificities involved in the receptor binding and nuclear retention of various androgens. Journal of Biological Chemistry 248 6154-6162.

Mauvais-Jarvis P, Kuttenn F \& Baudot N 1974 Inhibition of testosterone conversion to dihydrotestosterone in men treated percutaneously by progesterone. Journal of Clinical Endocrinology and Metabolism 38 142-147. (doi:10.1210/jcem-38-1-142)

Meriggiola MC \& Bremner WJ 1997 Progestin-androgen combination regimens for male contraception. Journal of Andrology 18 240-244.

Meriggiola MC \& Pelusi G 2006 Advances in male hormonal contraception. Expert Opinion on Investigational Drugs 15 389-397. (doi:10.1517/ 13543784.15.4.389)

Meriggiola MC, Costantino A, Saad F, D'Emidio L, Morselli Labate AM, Bertaccini A, Bremner WJ, Rudolph I, Ernst M, Kirsch B et al. 2005 Norethisterone enanthate plus testosterone undecanoate for male contraception: effects of various injection intervals on spermatogenesis, reproductive hormones, testis, and prostate. Journal of Clinical Endocrinology and Metabolism 90 2005-2014. (doi:10.1210/jc.2004-1852)

Meriggiola MC, Cerpolini S, Bremner WJ, Mbizvo MT, Vogelsong KM, Martorana G \& Pelusi G 2006 Acceptability of an injectable male contraceptive regimen of norethisterone enanthate and testosterone undecanoate for men. Human Reproduction 21 2033-2040. (doi:10. 1093/humrep/del094)

Mooradian AD, Morley JE \& Korenman SG 1987 Biological actions of androgens. Endocrine Reviews 8 1-28. (doi:10.1210/edrv-8-1-1)

Morali G, Lemus AE, Munguia R, Arteaga M, Perez-Palacios G, Sundaram K, Kumar N \& Bardin CW 1993 Induction of male sexual behavior in the rat by 7 alpha-methyl-19-nortestosterone, an androgen that does not undergo 5 alpha-reduction. Biology of Reproduction 49 577-581. (doi:10.1095/biolreprod49.3.577)

Morali G, Larsson K \& Beyer C 1977 Inhibition of testosterone-induced sexual behavior in the castrated male rat by aromatase blockers. Hormones and Behavior 9 203-213. (doi:10.1016/0018-506X (77)90056-3)

Perez-Palacios G, Fernandez-Aparicio MA, Medina M, Zacarias-Villareal J \& Ulloa-Aguirre A 1981 On the mechanism of action of progestins. Acta Endocrinologica 97 320-328.

Simons SS Jr 2008 What goes on behind closed doors: physiological versus pharmacological steroid hormone actions. Bioessays $30 \quad 744-756$. (doi:10.1002/bies.20792) 
Sundaram K, Kumar N \& Bardin CW 19947 Alpha-methyl-19-nortestosterone: an ideal androgen for replacement therapy. Recent Progress in Hormone Research 49 373-376.

Sundaram K, Kumar N, Monder C \& Bardin CW 1995 Different patterns of metabolism determine the relative anabolic activity of 19-norandrogens. Journal of Steroid Biochemistry and Molecular Biology 53 253-257. (doi:10.1016/0960-0760(95)00056-6)

Suvisaari J, Sundaram K, Noe G, Kumar N, Aguillaume C, Tsong YY, Lahteenmaki P \& Bardin CW 1997 Pharmacokinetics and pharmacodynamics of 7alpha-methyl-19-nortestosterone after intramuscular administration in healthy men. Human Reproduction 12 967-973. (doi:10.1093/humrep/12.5.967)

Vanderschueren D, Vandenput L, Boonen S, Lindberg MK, Bouillon R \& Ohlsson C 2004 Androgens and bone. Endocrine Reviews 25 389-425. (doi:10.1210/er.2003-0003)
Walton MJ, Kumar N, Baird DT, Ludlow H \& Anderson RA 2007 7Alphamethyl-19-nortestosterone (MENT) vs testosterone in combination with etonogestrel implants for spermatogenic suppression in healthy men. Journal of Andrology 28 679-688. (doi:10.2164/jandrol.107.002683)

Zmuda JM, Fahrenbach MC, Younkin BT, Bausserman LL, Terry RB, Catlin DH \& Thompson PD 1993 The effect of testosterone aromatization on high-density lipoprotein cholesterol level and postheparin lipolytic activity. Metabolism 42 446-450. (doi:10.1016/0026-0495(93)90101-S)

Received 18 May 2011

First decision 13 June 2011

Revised manuscript received 26 October 2011

Accepted 7 November 2011 